\title{
Identification of polyhydroxyalkanoates in Halococcus and other haloarchaeal species
}

\author{
Andrea Legat • Claudia Gruber • Klaus Zangger • \\ Gerhard Wanner $\cdot$ Helga Stan-Lotter
}

Received: 19 February 2010 /Revised: 9 April 2010 / Accepted: 9 April 2010 /Published online: 2 May 2010

(C) The Author(s) 2010. This article is published with open access at Springerlink.com

\begin{abstract}
Polyhydroxyalkanoates (PHAs) are accumulated in many prokaryotes. Several members of the Halobacteriaceae produce poly-3-hydroxybutyrate (PHB), but it is not known if this is a general property of the family. We evaluated identification methods for PHAs with 20 haloarchaeal species, three of them isolates from Permian salt. Staining with Sudan Black B, Nile Blue A, or Nile Red was applied to screen for the presence of PHAs. Transmission electron microscopy and ${ }^{1} \mathrm{H}$-nuclear magnetic resonance spectroscopy were used for visualization of PHB granules and chemical confirmation of PHAs in cell extracts, respectively. We report for the first time the production of PHAs by Halococcus sp. (Halococcus morrhuae DSM $1307^{\mathrm{T}}$, Halococcus saccharolyticus DSM $5350^{\mathrm{T}}$, Halococcus salifodinae DSM $8989^{\mathrm{T}}$, Halococcus dombrowskii DSM $14522^{\mathrm{T}}$, Halococcus hamelinensis JCM $12892^{\mathrm{T}}$, Halococcus qingdaonensis $\mathrm{JCM} 13587^{\mathrm{T}}$ ), Halorubrum sp. (Hrr. coriense DSM $10284^{\mathrm{T}}$, Halorubrum chaoviator DSM $19316^{\mathrm{T}}$, Hrr.
\end{abstract}

Electronic supplementary material The online version of this article (doi:10.1007/s00253-010-2611-6) contains supplementary material, which is available to authorized users.

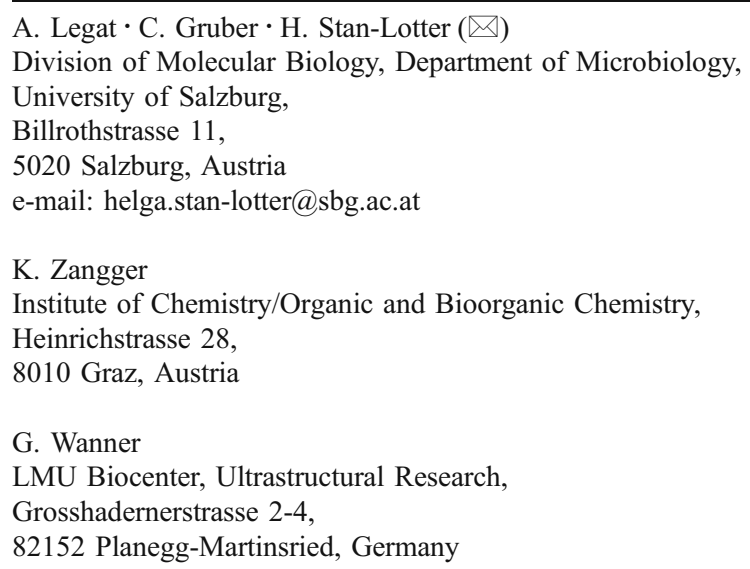

chaoviator strains NaxosII and AUS-1), haloalkaliphiles (Natronobacterium gregoryi NCMB 2189 , Natronococcus occultus DSM $3396^{\mathrm{T}}$ ) and Halobacterium noricense DSM $9758^{\mathrm{T}}$. No PHB was detected in Halobacterium salinarum NRC-1 ATCC 700922, Hbt. salinarum R1 and Haloferax volcanii DSM $3757^{\mathrm{T}}$. Most species synthesized PHAs when growing in synthetic as well as in complex medium. The polyesters were generally composed of PHB and poly- $\beta$ hydroxybutyrate-co-3-hydroxyvalerate (PHBV). Available genomic data suggest the absence of PHA synthesis in some haloarchaea and in all other Euryarchaeota and Crenarchaeota. Homologies between haloarchaeal and bacterial PHA synthesizing enzymes had indicated to some authors probable horizontal gene transfer, which, considering the data obtained in this study, may have occurred already before Permian times.

Keywords Polyhydroxybutyrate · Haloarchaea . Halococcus $\cdot$ Halobacterium $\cdot$ Haloalkaliphile

\section{Introduction}

Polyhydroxyalkanoates (PHAs) are produced and accumulated in prokaryotes as carbon and energy storage materials (Rehm 2003). They are water-insoluble polymers and stored in the cell cytoplasm as granules. Chemically, they consist mostly of poly- $\beta$-hydroxybutyrate (PHB) and polyß-hydroxyvalerate or copolymers (poly- $\beta$-hydroxybutyrateco-3-hydroxyvalerate; PHBV). In recent years, PHAs have attracted increasing attention due to their biodegradable, biocompatible, and thermoplastic features; they could be substitutes for petrochemical-derived plastics and be used as packaging and biomedical materials (Madison and Huisman 1999). 
The presence of PHA granules in haloarchaea was first reported in 1972 (Kirk and Ginzburg 1972). The strains were called at that time "Halobacterium sp. from the Dead Sea", but later identified as Haloarcula marismortui (Oren et al. 1990). Since then, strains of several other haloarchaeal genera, including Haloferax, Halobiforma, and Haloquadratum, have been found to accumulate PHAs, such as poly (3-hydroxybutyrate) or poly(3-hydroxybutyrate-co-hydroxyvalerate) (Fernandez-Castillo et al. 1986; Hezayen et al. 2002a; Burns et al. 2000). A recent review (Quillaguamán et al. 2010) lists PHA production by halophilic Archaea and Bacteria, with a focus on Haloferax mediterranei, which shows the highest potential of an archaeal source for industrial applications, and the characterization of enzymes involved in synthesis of PHA. No members of the genus Halococcus nor haloalkaliphiles, which grow optimally at $\mathrm{pH}$ values between 9 and 9.5 were yet reported to produce PHAs. In 2002, the first PHB synthase from an extremely halophilic archaeon was isolated from strain 56 (Hezayen et al. 2002b); this strain has been classified recently as Halopiger aswanensis (Hezayen et al. 2009).

In this work, species from several haloarchaeal genera, including members of the genus Halococcus, some haloalkaliphiles, and three isolates from Permo-Triassic rock salt (Halococcus salifodinae DSM $8989^{\mathrm{T}}$ [Denner et al. 1994], Halococcus dombrowskii DSM $14522^{\mathrm{T}}$ [Stan-Lotter et al. 2002] and Halobacterium noricense DSM $9758^{\mathrm{T}}$ [Gruber et al. 2004]), were investigated for the production of PHAs to learn more about the distribution of this capacity, which might lead to the detection of novel producers, and to find rapid and simple methods of identification of the polyesters.

\section{Material and methods}

Archaeal and bacterial strains

The following strains were obtained from the DSMZ (Deutsche Sammlung von Mikroorganismen und Zellkulturen GmbH, Inhoffenstraße 7 B, 38124 Braunschweig, Germany): Haloarcula hispanica DSM 4426 ${ }^{\mathrm{T}}$, Hbt. noricense DSM $9758^{\mathrm{T}}$, Halococcus morrhuae DSM $1307^{\mathrm{T}}$, Hcc. dombrowskii DSM $14522^{\mathrm{T}}$, Halococcus saccharolyticus DSM 5350 $0^{\mathrm{T}}$ Hcc. salifodinae DSM $8989^{\mathrm{T}}$, Hfx. mediterranei DSM $1411^{\mathrm{T}}$, Haloferax volcanii DSM $3757^{\mathrm{T}}$, Haloquadratum walsbyi DSM 16790, Halorubrum coriense DSM $10284^{\mathrm{T}}$, Natronococcus occultus DSM $3396^{\mathrm{T}}$, and Bacillus megaterium DSM $32^{\mathrm{T}}$. Strains Halococcus hamelinensis JCM $12892^{\mathrm{T}}$ and Halococcus qingdaonensis $\mathrm{JCM} 13587^{\mathrm{T}}$ were obtained from the Japan Collection of Microorganisms (RIKEN BioResource Center, 2-1 Hirosawa, Wako, Saitama 351-0198, Japan). Halorubrum chaoviator strains Halo-G* (DSM
$19316^{\mathrm{T}}$ ), AUS-1 and Naxos II were isolates from Baja California, Western Australia and Naxos, Greece, respectively (see Mancinelli et al. 2009). Halobacterium salinarum NRC-1 (ATCC-700922) was purchased from LGC Teddington, UK. Cells of Natronobacterium gregoryi NCMB $2189^{\mathrm{T}}$ and Hbt. salinarum R1 were gifts from Dr. Lawrence Hochstein, formerly at NASA Ames Research Center, USA.

Culture conditions

Strains were grown at $37{ }^{\circ} \mathrm{C}$ in side arm flasks in an incubator (Innova 4080) with a shaking platform (180 rpm). Growth in liquid culture was monitored spectrophotometrically at $520 \mathrm{~nm}$ (for synthetic media), or $600 \mathrm{~nm}$ (for complex media), respectively, using a Novaspec II photometer (Pharmacia). All strains were grown in both synthetic as well as in complex medium, unless indicated otherwise.

Synthetic media Basal synthetic medium was prepared similarly as described by Lillo and Rodriguez-Valera (1990); the $\mathrm{pH}$ was adjusted to 7.2 with $\mathrm{NaOH}$. For growth of haloalkaliphiles, the $\mathrm{NaCl}$ content of the medium was increased to $200 \mathrm{~g} / \mathrm{l}$ and $\mathrm{MgSO}_{4}$ was reduced to $2 \mathrm{~g} / \mathrm{l}$; the $\mathrm{pH}$ was adjusted to 9.0 with $\mathrm{NaOH}$.

Complex media Halococcus species and Hbt. salinarum R1 were cultured in M2 complex medium for neutrophilic halobacteria (Tomlinson and Hochstein 1976), except for Hcc. hamelinensis $\mathrm{JCM} 12892^{\mathrm{T}}$ and Hcc. qingdaonensis JCM $13587^{\mathrm{T}}$, which were grown in DSM medium 372 (http://www.dsmz.de/microorganisms/medium/pdf/DSMZ Medium372.pdf). Hqr. walsbyi (DSM 16790) was grown in JCM medium 457 (Bolhuis et al. 2004), Hbt. salinarum NRC-1 was grown in ATCC 2185 medium (Gruber et al. 2004); Hbt. noricense DSM $9758^{\mathrm{T}}$ was grown in modified Halobaculum gomorrense medium DSM 823 (Gruber et al. 2004), Nbt. gregoryi NCMB $2189^{\mathrm{T}}$ was grown in DSM medium 371 (http://www.dsmz.de/microorganisms/medium/ pdf/DSMZ_Medium371.pdf), which had a final $\mathrm{pH}$ of 9.09.5. B. megaterium DSM $32^{\mathrm{T}}$ was grown in nutrient broth, which contained (gram per liter): peptone 5 ; meat extract 3 ; the $\mathrm{pH}$ was adjusted to 7.0.

Staining procedures and microscopy

For staining, cells from early stationary growth phase were used; with few exceptions, cell density was high enough for direct microscopic observations. In the case of very low ODs (less than ca. 0.2) cells were concentrated by a factor of about 10 by centrifugation and resuspension. 
Staining of cells with Sudan black B (Murray et al. 1994) Smears of cells deposited on a glass slide were heatfixed and stained with a $3 \%(w / v$ in $70 \%$ ethanol $)$ solution of Sudan Black B (Sigma) for $10 \mathrm{~min}$, followed by immersion of the slide in xylene until it was completely decolorized. The sample was counterstained with safranin (Sigma; $5 \% \mathrm{w} / v$ in deionized water) for $10 \mathrm{~s}$, washed with water and dried. A few drops of immersion oil were added directly on the completely dry slide, and the cells were examined by phase contrast microscopy (Leica DM5000B).

Staining of cells with Nile Blue A (Ostle and Holt 1982) A $1 \%$ aqueous solution of Nile blue A (Sigma), was mildly heated and filtered before use (Ostle and Holt 1982). Heatfixed smears of archaeal cells were stained with the Nile blue A solution at $55{ }^{\circ} \mathrm{C}$ in a water bath for $10 \mathrm{~min}$ or, in the case of Halococcus species, for 15 min. After staining, slides were washed with tap water followed by an $8 \%$ acetic acid solution for $1 \mathrm{~min}$, washed again, and finally the stained smear was blotted dry with bibulous paper (remoistened with tap water) and covered with a glass cover slip. The samples were examined with a Leica DM5000B fluorescence microscope and observed with blue excitation wavelengths (filter BP 450-490).

Colony staining with Nile Red (Spiekermann et al. 1999) Nile Red (Sigma) was added from a stock solution of $25 \%$ $(v / v)$ in dimethylsulfoxide to agar media at a final concentration of $0.5 \mu \mathrm{g} / \mathrm{ml}$. Following growth, agar plates were exposed to UV light $(365 \mathrm{~nm})$ from a transilluminator (Type TFC-20 M; Vilber Lourmat, France) and photographed with a digital camera (Nikon COOLPIX S225).

Microscopes and acquisition of images For fluorescence and phase contrast microscopy, a Leica microscope type DM5000B with a mercury lamp (Hg100W; Leica Microsystems, Wetzlar, Germany), camera type DFC300FX (Leica Microsystems DI Cambridge) combined with the Leica Application Suite software 2.8.1 was used. Pictures were contrast-enhanced with Photoshop version 8.0.

Transmission electron microscopy (TEM) TEM was performed as described previously (Denner et al. 1994; Witte et al. 1990). Briefly, cells were fixed with $2 \%$ glutaraldehyde, stained with $3 \%$ lead citrate, and examined in a Siemens Elmiscop 101.

Chemical analysis of PHAs

Preparation of samples One hundred milliliters each of haloarchaeal cultures were obtained by growing cells of
Hfx. mediterranei DSM $1411^{\mathrm{T}}$ and Har. hispanica DSM $4426^{\mathrm{T}}$ in the basal synthetic medium supplemented with $1 \%(w / v)$ glucose (see above). All other strains were grown in complex media as described in "Materials and methods" section. Cells were harvested by centrifugation at 7,000 rpm for $30 \mathrm{~min}$ at $20{ }^{\circ} \mathrm{C}$ in a SLA-3000 rotor in a Sorvall RC6 centrifuge. Cell pellets were washed with $30 \mathrm{ml}$ sterile $\mathrm{TN}$ buffer $(4 \mathrm{M} \mathrm{NaCl}$ and $50 \mathrm{mM}$ Tris, $\mathrm{pH}$ 7.4) and centrifuged again. Pellets were transferred into sterile plastic tubes (1.5 ml volume each), frozen at $-70{ }^{\circ} \mathrm{C}$ and subjected to lyophilisation on a laboratory freeze dryer Type Freezone 12 (Labconco). The dry weight of the freeze-dried samples was determined gravimetrically.

For extraction and enrichment of PHAs from haloarchaeal cells, two methods were used: (1) treatment with sodium hypochlorite which was performed similar as described by Lillo and Rodriguez-Valera (1990). Cells were incubated with $0.2 \%$ (weight per volume) sodium hypochlorite for $1.5-2 \mathrm{~h}$ at $37{ }^{\circ} \mathrm{C}$ and centrifuged; the pellets were washed with distilled water, acetone and finally $96 \%$ ethanol, followed by freeze-drying. (2) Repeated washing of haloarchaeal cells with water, which resulted in lysis of cells (Grant et al. 2001) and, following centrifugation, left an insoluble whitish residue, which contained PHAs. Following four to five washes with water, the material was freeze dried. In some cases, washes were done with aqueous $0.1 \%(w / v)$ sodium dodecyl sulfate solution instead of water, which improved yields slightly.

Nuclear magnetic resonance (NMR) spectroscopic analysis of PHB and PHBV in cell extracts To determine the amounts of PHB and PHBV, 20-70 mg of lyophilized cells were shaken with $1 \mathrm{ml}$ of deuterochloroform $\left(\mathrm{CDCl}_{3}\right)$ for $10 \mathrm{~min}$ and sonicated for another $15 \mathrm{~min}$ to solubilize PHB and PHBV. After centrifugation, $20 \mathrm{mg}$ ethyl sulfone was added to the supernatant as internal standard. One-dimensional ${ }^{1} \mathrm{H}$ NMR spectra with 128 scans were acquired on a Bruker AMX $360 \mathrm{MHz}$ NMR spectrometer at $298{ }^{\circ} \mathrm{K}$ (Mukhopadhyay et al. 2005). Alternatively, spectra were obtained with a Varian Unity300 spectrometer, operating at $299.94 \mathrm{MHz}$. For quantification, the signals of the methine protons at 3-position of PHB $\left(\delta\left({ }^{1} \mathrm{H}\right)=5.25 \mathrm{ppm}\right)$ and PHBV $\left(\delta\left({ }^{1} \mathrm{H}\right)=5.17 \mathrm{ppm}\right)$ were integrated and compared to the ethyl sulfone $\mathrm{CH}_{2}$ signal $\left(\delta\left({ }^{1} \mathrm{H}\right)=3.00 \mathrm{ppm}\right)$; in some experiments, quantification was done with benzene $\left(\delta\left({ }^{1} \mathrm{H}\right)=7.28 \mathrm{ppm}\right)$. Lyophilized cell extracts, which were enriched for PHAs (see above), were treated similarly, except that the volumes of reagents were scaled down appropriately, since the dry weights were usually in the range of $\leq 5-10 \mathrm{mg}$, and the number of scans was increased to 1,024 . 


\section{Results}

Light and electron microscopical detection of PHA granules

The lipophilic stain Sudan Black B has long been regarded as a dye with particular high affinity for PHAs (Murray et al. 1994). Ostle and Holt (1982) demonstrated a higher specificity of the fluorescent dye Nile Blue A, a basic oxazine dye, for PHB. Both stains were applied here to cultures of haloarchaeal species. Following staining with Sudan Black B, stationary phase cells of haloarchaeal species contained prominent dark granules, as shown for Hcc. morrhuae DSM $1307^{\mathrm{T}}$ in Fig. S1 (Online resource).

Staining with Nile Blue A was performed with cells of two strains, which are known producers of PHB, Hfx. mediterranei DSM $1411^{\mathrm{T}}$ (Lillo and Rodriguez-Valera 1990) and Hqr. walsbyi DSM 16790 (Burns et al. 2007). Fluorescence microscopy at an excitation wavelength of $460 \mathrm{~nm}$ revealed numerous brightly fluorescent orange granules within the cells (Online resource, Fig. S2, A, C). Phase contrast micrographs of the same cells allowed already the detection of granules in $H f x$. mediterranei DSM $1411^{\mathrm{T}}$ and Hqr. walsbyi DSM 16790 as light refracting areas within the cytoplasm (Online resource, Fig. S2, B, D). Six species of the genus Halococcus (Hcc. salifodinae DSM 8989 ${ }^{\mathrm{T}}$, Hcc. hamelinensis $\mathrm{JCM} 12892^{\mathrm{T}}$, Hcc. dombrowskii DSM $14522^{\mathrm{T}}$, Hcc. qingdaonensis JCM $13587^{\mathrm{T}}$, Hcc. saccharolyticus DSM 5350 ${ }^{\mathrm{T}}$, Hcc. morrhuae DSM $1307^{\mathrm{T}}$ ) contained roundish granules of bright orange fluorescence within their cells, following staining with Nile Blue A (Fig. 1a-f). Six further haloarchaeal species are shown in Fig. S3 (Online resource): similar orange granules were detected in Hbt. noricense DSM 9758 ${ }^{\mathrm{T}}$, Ncc. occultus DSM 3396 ${ }^{\mathrm{T}}$, Halorubrum species (Hrr. coriense DSM $10284^{\mathrm{T}}$, Hrr. chaoviator DSM 19316 ${ }^{\mathrm{T}}$, Hrr. chaoviator strain NaxosII), and Har. hispanica DSM 4426 ${ }^{\mathrm{T}}$. In most cells, the granules were visible as distinct entities against a dark background; however, some cells showed also diffuse staining which delineated roughly the cell morphology. We attribute this faint color to a certain affinity of the lipophilic dye Nile Blue A to membranes or haloarchaeal cell envelopes. The number of granules in the cells differed to
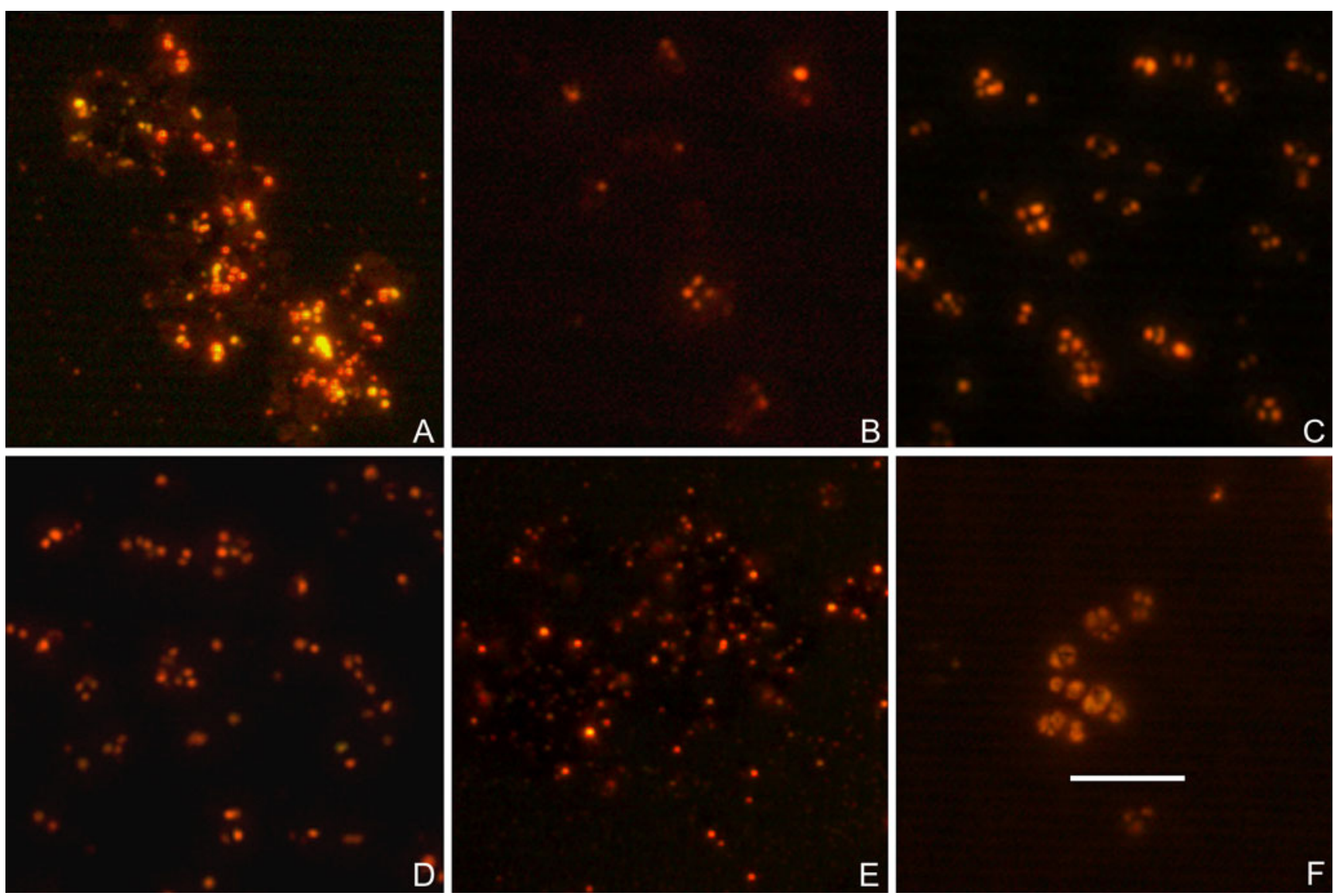

Fig. 1 Fluorescence microscopy of Halococcus species following staining with Nile Blue A. Growth media are indicated in brackets. First row: a Hcc. salifodinae DSM $8989^{\mathrm{T}}$ (M2 medium); b Hcc. hamelinensis JCM $12892^{\mathrm{T}}$ (DSM medium 372); c Hcc. dombrowskii
DSM $14522^{\mathrm{T}}$ (M2 medium). Second row: d Hcc. qingdaonensis JCM $13587^{\mathrm{T}}$ (DSM medium 372); e Hcc. saccharolyticus DSM 5350 ${ }^{\mathrm{T}}$ (M2 medium); f Hcc. morrhuae DSM $1307^{\mathrm{T}}$ (M2 medium). Bar $5 \mu \mathrm{m}$ 
some extent between the species; but in size and brightness, the orange fluorescent granules were similar as in the control organisms $H f x$. mediterranei DSM $1411^{\mathrm{T}}$ and $H q r$. walsbyi DSM 16790 (see Online resource, Fig. S2).

In Table 1, staining results are summarized for growth in synthetic or complex medium, with "+" denoting the presence of orange granules due to Nile Blue A, or dark granules, due to Sudan Black B. B. megaterium was used as a negative control since this organisms possesses the capacity for production of PHAs, but does so only under limitation of nutrients (Findlay and White 1983) and not in complex medium.

Early TEM had revealed clear zones within haloarchaeal cells which, together with results from X-ray diffraction patterns, were identified as PHB granules (Kirk and Ginzburg 1972); a recent TEM image of PHBV granules in $H f x$. mediterranei is displayed in Lu et al. (2008). Figure 2 shows a TEM photograph of Hcc. morrhuae DSM $1307^{\mathrm{T}}$ grown in
M2 medium for 7 days. Each cell appeared to contain one or more PHB granules, which are visible as white inclusion bodies within the cytoplasm. The size of the PHB granules ranged from approximately $0.05-0.30 \mu \mathrm{m}$ in diameter, as measured in the micrograph. While the structures in TEM pictures arise from random cuts through embedded material and therefore cannot be considered as an exact representation of the original material, the range of sizes was similar to the dimensions which were observed for bacterial PHB granules (Sudesh et al. 2000). Similar TEM pictures with PHB granules of comparable sizes were obtained with cells of Hcc. salifodinae DSM $8989^{\mathrm{T}}$ (not shown).

Incorporation of Nile Red into colonies and cells

A selective solid medium was proposed by Spiekermann et al. (1999), containing the fluorescent dye Nile Red, which
Table 1 PHB accumulation in haloarchaeal species detected by staining with Nile Blue A or Sudan Black B. Cells were grown in synthetic medium + $1 \%$ glucose and/or complex medium (type indicated in brackets; see "Material and methods" sections for composition). The presence of stainable granules is indicated by + (Nile Blue A; Sudan Black B), or no staining (-)

$N D$ not done

\begin{tabular}{|c|c|c|c|c|}
\hline \multirow[t]{2}{*}{ Organism } & \multicolumn{2}{|c|}{$\begin{array}{l}\text { Synthetic medium }+1 \% \\
\text { glucose }\end{array}$} & \multicolumn{2}{|l|}{ Complex medium } \\
\hline & Nile Blue A & Sudan Black B & Nile Blue A & Sudan Black B \\
\hline Hcc. dombrowskii DSM $14522^{\mathrm{T}}$ & + & + & $\begin{array}{l}+ \\
(\mathrm{M} 2)\end{array}$ & ND \\
\hline Hcc. salifodinae DSM $8989^{\mathrm{T}}$ & + & + & $\begin{array}{l}+ \\
(\mathrm{M} 2)\end{array}$ & ND \\
\hline Hcc. morrhuae DSM $1307^{\mathrm{T}}$ & + & + & $\begin{array}{l}+ \\
(\mathrm{M} 2)\end{array}$ & $\begin{array}{l}+ \\
(\mathrm{M} 2)\end{array}$ \\
\hline Hcc. saccharolyticus DSM $5350^{\mathrm{T}}$ & + & + & $\begin{array}{l}+ \\
\text { (M2) }\end{array}$ & ND \\
\hline Hcc. hamelinensis JCM $12892^{\mathrm{T}}$ & ND & ND & $\begin{array}{l}+ \\
\text { (DSM372) }\end{array}$ & ND \\
\hline Hcc. qingdaonensis JCM $13587^{\mathrm{T}}$ & ND & ND & $\begin{array}{l}+ \\
\text { (DSM372) }\end{array}$ & ND \\
\hline Ncc. occultus DSM $3396^{\mathrm{T}}$ & + & + & ND & ND \\
\hline Har. hispanica DSM $4426^{\mathrm{T}}$ & + & + & $\begin{array}{l}+ \\
\text { (M2) }\end{array}$ & ND \\
\hline Hfx. mediterranei DSM $1411^{\mathrm{T}}$ & + & + & $\begin{array}{l}+ \\
(\mathrm{M} 2)\end{array}$ & ND \\
\hline Hqr. walsbyi DSM 16790 & ND & ND & $\begin{array}{l}+ \\
(\mathrm{JCM} 457)\end{array}$ & $\begin{array}{l}+ \\
(\mathrm{JCM} 457)\end{array}$ \\
\hline Hbt. noricense DSM $9758^{\mathrm{T}}$ & + & + & $\begin{array}{l}+ \\
\text { (DSM823 mod.) }\end{array}$ & ND \\
\hline Hrr. coriense DSM $10284^{\mathrm{T}}$ & + & + & $\begin{array}{l}+ \\
(\mathrm{M} 2)\end{array}$ & ND \\
\hline Hrr. chaoviator DSM $19316^{\mathrm{T}}$ & + & + & $\begin{array}{l}+ \\
\text { (M2) }\end{array}$ & ND \\
\hline Hrr. chaoviator strain Naxos II & + & + & $\begin{array}{l}+ \\
\text { (M2) }\end{array}$ & ND \\
\hline Hrr. chaoviator strain AUS-1 & ND & ND & $\begin{array}{l}+ \\
\text { (M2) }\end{array}$ & ND \\
\hline $\begin{array}{l}\text { Negative control: } B . \text { megaterium } \\
\quad\left(\mathrm{DSM} 32^{\mathrm{T}}\right)\end{array}$ & ND & ND & $\begin{array}{l}- \\
\text { (nutrient broth) }\end{array}$ & $\begin{array}{l}- \\
\text { (nutrient broth) }\end{array}$ \\
\hline
\end{tabular}




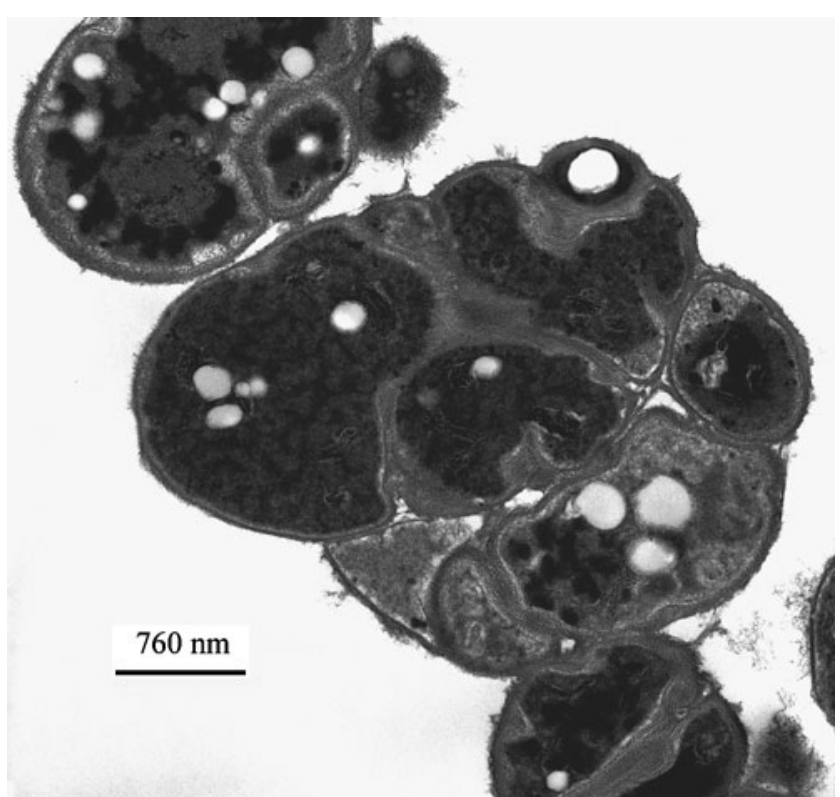

Fig. 2 Transmission electron micrograph of Hcc. morrhuae DSM $1307^{\mathrm{T}}$ grown in complex medium (M2) for 7 days. Cells contain whitish poly- $\beta$-hydroxybutyrate inclusion bodies

enables discrimination between PHA accumulating and nonPHA-accumulating cells. Addition of Nile Red in low concentration $(0.5 \mathrm{ug} / \mathrm{ml})$ did not inhibit growth of haloarchaeal strains and caused intense fluorescence of colonies under UV light of $365 \mathrm{~nm}$. Hfx. mediterranei DSM $1411^{\mathrm{T}}$ and $N c c$. occultus DSM $3396^{\mathrm{T}}$ are shown in Fig. S4 (Online resource); other haloarchaeal strains, which were fluorescent on Nile Red containing agar plates, were Har. hispanica DSM $4426^{\mathrm{T}}, \mathrm{Hbt}$. noricense DSM $9758^{\mathrm{T}}$, Hrr. chaoviator DSM 19316 ${ }^{\mathrm{T}}$, and Hrr. chaoviator strain NaxosII (not shown). No or only weak fluorescence was detected with colonies of $\mathrm{Hbt}$. salinarum NRC-1 (not shown). Cells from these plates were examined by fluorescence microscopy and exhibited orange-red staining, which confirmed the uptake of Nile Red (not shown).

A summary of the culturing conditions of haloarchaeal strains and the concomitant presence of stainable granules within cells, which suggested the production of PHAs, is given in Table 1. The cultures of the haloarchaeal strains were generally in their stationary growth phase when examined for PHAs. When synthetic medium was used, cell yields were in some cases low $(\mathrm{OD} \leq 0.2)$, as was to be expected from the known limited utilization of carbohydrates by some haloarchaea (Grant 2001a). Nevertheless, following concentration by centrifugation, enough biomass was obtained for successful staining experiments.

\section{Chemical detection of PHAs}

The content of PHAs was determined by proton NMR with chloroform extracts from freeze-dried cells and aqueous or hypochlorite extracts of cells. ${ }^{1} \mathrm{H}$ NMR spectra showed the characteristic peaks of PHB near 5.25 ppm and PHBV near 5.17 ppm (Jan et al. 1996; Mukhopadhyay et al. 2005), see Fig. S5 (Online resource). Table 2 shows the presence of PHAs synthesized by haloarchaeal species following analysis with ${ }^{1} \mathrm{H}$ NMR of extracts from freeze-dried cultures or fresh cells. The yield of PHAs was generally low and ranged from $0.06 \%$ to $0.25 \%$ of the cellular dry weight; however, it should be noted that no optimization of production of PHAs was attempted in this work. In addition, losses due to incomplete extraction of samples were likely occurring, as have been described previously for lipids and isoprenoids from haloarchaea (Kates and Kushwaha, 1995). Therefore, the numbers are to be considered the minimum amounts of PHAs in the respective strains. PHB was the main component produced by all investigated haloarchaeal species (Table 2); the copolymer PHBV was synthesized by several strains, but in much smaller amounts. Aqueous extracts yielded more enriched preparations from $H f x$. mediterranei DSM $1411^{\mathrm{T}}$ than was possible with chloroform treatment (about $69 \%$ PHB versus $0.2 \%$; Table 2), and a somewhat improved preparation from Hcc. dombrowskii DSM $14522^{\mathrm{T}}(0.4 \%$ PHB versus $0.15 \%$; Table 2). Hypochlorite extracts (Lillo and Rodriguez-Valera 1990) increased the yield of PHB from Nbt. gregoryi NCMB $2189^{\mathrm{T}}$ (Table 2). While the reproducibility of ${ }^{1} \mathrm{H}$ NMR spectra from the same sample was high (Table 2), variations between different preparations may be expected to be large, due to procedural influences as noted above.

\section{Information from genomics}

The classical route for the synthesis of PHA involves three enzymes (gene name in brackets): $\beta$-ketothiolase ( $p h a A$ ), acetoacetyl-CoA dehydrogenase ( $p h a B$ ), and poly(3hydroxyalkanoate) synthase ( $p h a C$ ), although some additonal pathways have been identifed recently (Kalia et al. 2007). To date, the sequences of 12 genomes of the Halobacteriaceae are available, e. g., in the website resource of EMBL (http://www.ebi.ac.uk/embl/): Har. marismortui ATCC 43049, Hbt. salinarum NRC-1 ATCC700922, Hbt. salinarum R1, Hfx. volcanii DS2, Halogeometricum borinquense DSM 11551, Halomicrobium mukohataei DSM 12286, Hqr. walsbyi DSM 16790, Halorhabdus utahensis DSM 12940, Halorubrum lacusprofundi ATCC 49239, Haloterrigena turkmenica DSM 5511, Natrialba magadii ATCC 43099, Natronomonas pharaonis DSM 2160. In six of these, Har. marismortui, Hgm. borinquense, Hmc. mukohataei, Hrd. utahensis, Hqr. walsbyi, and Htg. turkmenica, the phaC gene is present. Recently highly homologous genes (phaEC) were identified in Har. hispanica (Han et al. 2007) and $H f x$. mediterranei ( $\mathrm{Lu}$ et al. 2008), which are coding for two subunits $(\mathrm{E}, \mathrm{C})$ of the PHA synthase. The genome of 
Table 2 Contents of PHB and PHBV in haloarchaeal species, determined by proton NMR from cell extracts

\begin{tabular}{|c|c|c|c|c|c|c|}
\hline \multirow{3}{*}{ Organism } & \multicolumn{6}{|c|}{ Origin of material } \\
\hline & \multicolumn{2}{|c|}{ Freeze-dried cells } & \multicolumn{2}{|c|}{ Fresh cells, aqueous extract } & \multicolumn{2}{|c|}{ Fresh cells, hypochlorite extract } \\
\hline & $\begin{array}{l}\text { PHB } \\
w / w \% \text { of cell } \\
\text { dry weight }\end{array}$ & $\begin{array}{l}\text { PHBV } \\
w / w \% \text { of cell } \\
\text { dry weight }\end{array}$ & $\begin{array}{l}\text { PHB } \\
w / w \% \text { of } \\
\text { dried extract }\end{array}$ & $\begin{array}{l}\text { PHBV } \\
w / w \% \text { of } \\
\text { dried extract }\end{array}$ & $\begin{array}{l}\text { PHB } \\
w / w \% \text { of } \\
\text { dried extract }\end{array}$ & $\begin{array}{l}\text { PHBV } \\
w / w \% \text { of } \\
\text { dried extract }\end{array}$ \\
\hline Hfx. mediterranei DSM $1411^{\mathrm{T}}$ & $\begin{array}{l}0.19 \\
0.20\end{array}$ & $\begin{array}{l}0.03 \\
0.05\end{array}$ & $69.6 \pm 0.43^{\mathrm{a}}$ & $8.1 \pm 0.3^{\mathrm{a}}$ & ND & ND \\
\hline Hfx. volcanii DSM $3757^{\mathrm{T}}$ & ND & ND & Not detectable & Not detectable & ND & ND \\
\hline Hcc. dombrowskii DSM $14522^{\mathrm{T}}$ & 0.15 & 0.01 & $0.4 \pm 0^{\mathrm{a}}$ & $0.07 \pm 0.05^{\mathrm{a}}$ & 0.1 & Not detectable \\
\hline Hcc. salifodinae DSM $8989^{\mathrm{T}}$ & 0.05 & 0.01 & ND & ND & ND & ND \\
\hline Hcc. saccharolyticus DSM $5350^{\mathrm{T}}$ & ND & ND & 1.2 & Not detectable & 0.05 & Not detectable \\
\hline Har. hispanica DSM $4426^{\mathrm{T}}$ & 0.09 & 0.04 & ND & ND & ND & ND \\
\hline Hbt. salinarum $\mathrm{R} 1$ & Not detectable & Not detectable & ND & ND & ND & ND \\
\hline Hbt. salinarum NRC-1 ATCC 700922 & ND & ND & Not detectable & Not detectable & Not detectable & Not detectable \\
\hline Hbt. noricense DSM $9758^{\mathrm{T}}$ & 0.08 & 0.03 & ND & ND & ND & ND \\
\hline Hqr. walsbyi DSM 16790 & ND & ND & 0.1 & Not detectable & ND & ND \\
\hline Nbt. gregoryi $\mathrm{NCMB} 2189^{\mathrm{T}}$ & $\begin{array}{l}0.1 \\
0.44\end{array}$ & $\begin{array}{l}0.03 \\
0.18\end{array}$ & 0.1 & Not detectable & 0.4 & Not detectable \\
\hline Ncc. occultus DSM $3396^{\mathrm{T}}$ & ND & ND & ND & ND & 3.1 & Not detectable \\
\hline
\end{tabular}

Freeze-dried cells were treated with $\mathrm{CDCl}_{3}$ and sonicated prior to ${ }^{1} \mathrm{H}$ NMR analysis (see Methods); cell dry weights ranged from 33 to $170 \mathrm{mg}$. Water and hypochlorite extracts were prepared from fresh cells (see Methods for details) and ranged from 2 to $10 \mathrm{mg}$

ND not done

${ }^{\mathrm{a}}$ Mean value \pm standard deviation from three experiments each

Hbt. salinarum NRC-1 ATCC700922 contains homologues of genes phaA and phaB, but not of $p H a C$ (Kalia et al. 2007). Using the HaloLex system (http://www.halolex.mpg.de/ public/; see Pfeiffer et al. 2008), it is apparent that none of the available 43 genomes from Crenarchaeota and Euryarchaeota contain $p h a E / C$ genes.

\section{Discussion}

A useful screening method for the presence of PHAs is the incorporation of the dye Nile Red into colonies on agar plates and its detection by fluorescence (Spiekermann et al. 1999). The method has been used widely for the rapid identification of PHA-producing environmental bacteria (e.g., Berlanga et al. 2006), but not yet with archaea. In our experiments, correct predictions from the presence or absence of fluorescent colonies for the production of PHAs were obtained also for haloarchaeal strains. The method can thus be considered compatible with agar plates containing media of high ionic strength. Other methods which were used here included staining for cytoplasmic granules of PHB in cells, which is fast and generally informative. As noted earlier by Ostle and Holt (1982), Nile Blue A apparently has a greater affinity for PHB than Sudan Black
B and, in connection with fluorescence microscopy, leads to superior images with high contrast. However, weak fluorescence indicative of unspecific binding to cell components, due to the lipophilic nature of Nile Blue A, may occasionally occur and lead to ambiguous results. Transmission electron microscopy is a superior method for visualizing PHB granules (see Fig. 2), but it is not a simple procedure. Chemical analysis is the preferable identification method, with the provision, that enough sample material must be used, especially when "weak PHA producers", such as most haloarchaea, are investigated, which are not stimulated by carbohydrates (Grant 2001a).

Strains of several haloarchaeal genera use carbohydrates as sources of carbon and energy, most notably $H f x$. mediterranei, which has so far been identified as the best haloarchaeal PHA producer. PHA was detected in this work in strains from the genus Halorubrum (Hrr. coriense; three strains of Hrr. chaoviator), the genus Haloarcula (Har. hispanica) and the genus Halococcus (Hcc. saccharolyticus); since these strains are known to utilize various carbohydrates (McGenity and Grant 1995; Ventosa 2001; Grant 2001b), an investigation into the efficiency of their PHA production from different substrates may be warranted.

Haloalkaliphilic archaea, which require both alkaline conditions and high salt for growth (Kamekura 1998) were 
shown here to include PHA producers (Nbt. gregoryi NCMB $2189^{\mathrm{T}}$, Ncc. occultus DSM $3396^{\mathrm{T}}$ ). The apparently high concentration of stainable granules in Ncc. occultus might indicate a rather profuse production of PHAs (see Online resource, Fig. S3).

The data presented here suggested that PHA granules were formed by many haloarchaeal strains during growth in both synthetic and complex media. It is likely that those haloarchaea constitutively produce the enzymes for synthesis of PHAs and accumulate the polymers continuously at low levels, independently of nutrient-rich or nutrientlimited conditions, similarly as shown for Har. marismortui (Han et al. 2007). The advantage for the cells would presumably be a fast response to changing environmental conditions with the commencement of production of storage materials.

Information from genome sequences about PHA synthases is still sparse. Of interest is the finding that high homologies exist to the bacterial set of enzymes as reported by several authors (Baliga et al. 2004; Bolhuis et al. 2006; Han et al. 2007; Lu et al. 2008; Quillaguamán et al. 2010), which suggests horizontal gene transfer (Kalia et al. 2007). Hbt. salinarum NRC-1 apparently acquired only two of the three enzymes, $p H a A$ and $p h a B$, but not $p h a C$.

Six representatives of species from the genus Halococcus were shown here for the first time to produce PHA (Tables 1, 2; Fig. 1). Their geographical origins are globalHamelin Pool, Shark Bay, Australia; Alpine salt, Austria; Qingdao beach, China; saltern in Cadiz, Southern Spain; salted fish from North American sea water. In addition, two of them (Hcc. salifodinae DSM $8989^{\mathrm{T}}$, Hcc. dombrowskii DSM $14522^{\mathrm{T}}$ ) are isolates from Permo-Triassic rock salt, as is the rod-shaped Hbt. noricense DSM $9758^{\mathrm{T}}$, which also contains PHAs (Tables 1, 2; Fig. S3, Online resource). It may be concluded that the transfer of all necessary enzymes has possibly occurred into these haloarchaea already some 250 million years ago.

Acknowledgments This work was supported in part by the Austrian Science Foundation (FWF) project P18256-B06 to HSL. We thank Tobias Madl and Bernd Werner, both University of Graz, for carrying out the NMR analysis of PHAs, and John Edwards, Process NMR Associates LLC, Danbury, USA, for several NMR spectra.

Open Access This article is distributed under the terms of the Creative Commons Attribution Noncommercial License which permits any noncommercial use, distribution, and reproduction in any medium, provided the original author(s) and source are credited.

\section{References}

Baliga NS, Bonneau R, Facciotti MT, Pan M, Glusman G, Deutsch EW, Shannon P, Chiu Y, Weng RS, Gan RR, Hung P, Date SV, Marcotte E, Hood L, Ng WV (2004) Genome sequence of
Haloarcula marismortui: a halophilic archaeon from the Dead Sea. Genome Res 14:2221-2234

Berlanga M, Montero MT, Hernández-Borrell J, Guerrero R (2006) Rapid spectrofluorometric screening of poly-hydroxyalkanoateproducing bacteria from microbial mats. Int Microbiol 9:95-102

Bolhuis H, te Poele EM, Rodriguez-Valera F (2004) Isolation and cultivation of Walsby's square archaeon. Environ Microbiol 6:1287-1291

Bolhuis H, Palm P, Wende A, Falb M, Rampp M, Rodriguez-Valera F, Pfeiffer F, Oesterhelt D (2006) The genome of the square archaeon Haloquadratum walsbyi: life at the limits of water activity. BMC Genomics 7:169

Burns DG, Camakaris HM, Janssen PH, Dyall-Smith ML (2000) Cultivation of Walsby's sqare haloarchaeon. FEMS Microbiol Lett 238:469-473

Burns DG, Janssen PH, Itoh T, Kamekura M, Li Z, Jensen G, Rodríguez-Valera F, Bolhuis H, Dyall-Smith ML (2007) Haloquadratum walsbyi gen. nov., sp. nov., the square haloarchaeon of Walsby, isolated from saltern crystallizers in Australia and Spain. Int J Syst Evol Microbiol 57:387-392

Denner EBM, McGenity TJ, Busse H-J, Grant WD, Wanner G, StanLotter H (1994) Halococcus salifodinae sp. nov., an archaeal isolate from an Austrian salt mine. Int J Syst Bacteriol 44:774-780

Fernandez-Castillo R, Rodriguez-Valera F, Gonzalez-Ramos J, RuizBerraquero F (1986) Accumulation of poly(-hydroxybutyrate) by halobacteria. Appl Environ Microbiol 51:214-216

Findlay RH, White DC (1983) Polymeric beta-hydroxyalkanoates from environmental samples and Bacillus megaterium. Appl Environ Microbiol 45:71-78

Grant WD (2001a) Genus I. Halobacterium Elazari-Volcani 1957, $207,{ }^{\mathrm{AL}}$ emend. Larsen and Grant 1989, 2222. In: Boone DR, Castenholz RW, Garrity GM (eds) Bergey's manual of systematic bacteriology, vol. I, 2nd edn. Springer Verlag, New York, pp 301-305

Grant WD (2001b) Genus IV. Halococcus Schoop 1935a, 817 ${ }^{\mathrm{AL}}$. In: Boone DR, Castenholz RW, Garrity GM (eds) Bergey's manual of systematic bacteriology, vol. I, 2nd edn. Springer Verlag, New York, pp 311-314

Grant WD, Kamekura M, McGenity TJ, Ventosa (2001) Order I. Halobacteriales Grant and Larsen 1989b, 495 ${ }^{\mathrm{VP}}$ (Effective publication: Grant and Larsen 1989a, 2216). In Boone DR, Castenholz RW, Garrity GM (ed) Bergey's manual of systematic bacteriology, second Ed, vol. I. Springer Verlag, New York, pp. 294-301

Gruber C, Legat A, Pfaffenhuemer M, Radax C, Weidler G, Busse HJ, Stan-Lotter H (2004) Halobacterium noricense sp. nov., an archaeal isolate from a bore core of an alpine Permian salt deposit, classification of Halobacterium sp. NRC-1 as a strain of $H$. salinarum and emended description of $H$. salinarum. Extremophiles 8:431-439

Han J, Lu Q, Zhou L, Zhou J, Xiang H (2007) Molecular characterization of the $p h a E C_{H m}$ genes, required for biosynthesis of poly(3-hydroxybutyrate) in the extremely halophilic archaeon Haloarcula marismortui. Appl Environ Microbiol 73:6058-6065

Hezayen FF, Tindall BJ, Steinbüchel A, Rehm BHA (2002a) Characterization of a novel halophilic archaeon, Halobiforma haloterrestris gen. nov., sp. nov., and transfer of Natronobacterium nitratireducens to Halobiforma nitratireducens comb. nov. Int J Syst Evol Microbiol 52:2271-2280

Hezayen FF, Steinbüchel A, Rehm BHA (2002b) Biochemical and enzymological properties of the polyhydroxybutyrate synthase from the extremely halophilic archaeon strain 56. Arch Biochem Biophys 403:284-291

Hezayen FF, Gutierrez CM, Steinbüchel A, Tindall BJ, Rehm BH (2009) Halopiger aswanensis sp. nov., a polymer-producing, extremely halophilic archaeon isolated from hypersaline soil. Int J Syst Evol Microbiol. doi:10.1099/ijs.0.013078-0 
Jan S, Roblot C, Courtois J, Courtois B, Barbotin JN, Séguin JP (1996) ${ }^{1} \mathrm{H}$ NMR spectroscopic determination of poly 3hydroxybutyrate extracted from microbial biomass. Enzyme Microb Technol 18:195-201

Kalia VC, Lal S, Cheema S (2007) Insight in to the phylogeny of polyhydroxyalkanoate biosynthesis: horizontal gene transfer. Gene 389:19-26

Kamekura M (1998) Diversity of extremely halophilic bacteria. Extremophiles 2:289-295

Kates M, Kushwaha SC (1995) Isoprenoids and polar lipids of extreme halophiles in Archaea. In: DasSarma S, Fleischmann EM (eds) A laboratory manual. Halophiles. Cold Spring Harbor Laboratory Press, New York, pp 35-54

Kirk RG, Ginzburg M (1972) Ultrastructure of two species of halobacterium. J Ultrastruct Res 41:80-94

Lillo JG, Rodriguez-Valera F (1990) Effects of culture conditions on poly ( $\beta$-hydroxybutyric acid) production by Haloferax mediterranei. Appl Environ Microbiol 56:2517-2521

Lu Q, Han J, Zhou L, Zhou J, Xiang H (2008) Genetic and biochemical characterization of the poly(3-hydroxybutyrate-co3-hydroxyvalerate) synthase in Haloferax mediterranei. J Bacteriol 190:4173-4180

Madison LL, Huisman GW (1999) Metabolic engineering of poly(3hydroxyalkanoates): from DNA to plastic. Microbiol Mol Biol Rev 63:21-53

Mancinelli R, Landheim R, Sanchez-Porro C, Dornmayr-Pfaffenhuemer M, Gruber C, Legat A, Ventosa A, Radax C, Ihara K, White MR, Stan-Lotter H (2009) Halorubrum chaoviator, sp. nov., a haloarchaeon isolated from sea salt in Baja California, Mexico, Western Australia and Naxos, Greece. Int J Syst Evol Microbiol 59:1908-1913

McGenity TJ, Grant WD (1995) Transfer of Halobacterium saccharovorum, Halobacterium sodomense, Halobacterium trapanicum NRC 34021 and Halobacterium lacusprofundi to the genus Halorubrum gen. nov., as Halorubrum saccharovorum comb. nov., Halorubrum sodomense comb. nov., Halorubrum trapanicum comb. nov., and Halorubrum lacusprofundi comb. nov. Syst Appl Microbiol 18:237-243

Mukhopadhyay M, Patra A, Paul AK (2005) Production of poly(3hydroxybutyrate) and poly(3-hydroxybutyrate-co-3-hydroxyvalerate) by Rhodopseudomonas palustris SP5212. World J Microbiol Biotechnol 21:765-769
Murray RGE, Doetsch RN, Robinow CF (1994) Determinative and cytological light microscopy. In: Gerhardt P, Murray RGE, Wood WA, Krieg NR (eds) Manual of methods for general microbiology. American Society for Microbiology, Washington, pp 21-41

Oren A, Ginzburg M, Ginzburg BZ, Hochstein LI, Volcani BE (1990) Haloarcula marismortui (Volcani) sp. nov., nom. rev., an extremely halophilic bacterium from the Dead Sea. Int J Syst Bacteriol 40:209-210

Ostle AG, Holt JG (1982) Nile Blue A as a fluorescent stain for polybeta-hydroxybutyrate. Appl Environ Microbiol 44:238-241

Pfeiffer F, Broicher A, Gillich T, Klee K, Mejía J, Rampp M, Oesterhelt D (2008) Genome information management and integrated data analysis with HaloLex. Arch Microbiol 190:281-299

Quillaguamán J, Guzmán H, Van-Thuoc D, Hatti-Kaul R (2010) Synthesis and production of polyhydroxyalkanoates by halophiles: current potential and future prospects. Appl Microbiol Biotechnol 85:1687-1696

Rehm BH (2003) Polyester synthases: natural catalysts for plastics. Biochem J 376:15-33

Spiekermann P, Rehm BH, Kalscheuer R, Baumeister D, Steinbüchel A (1999) A sensitive, viable-colony staining method using Nile red for direct screening of bacteria that accumulate polyhydroxyalkanoic acids and other lipid storage compounds. Arch Microbiol 171:73-80

Stan-Lotter H, Pfaffenhuemer M, Legat A, Busse H-J, Radax C, Gruber C (2002) Halococcus dombrowskii sp. nov., an archaeal isolate from a Permian alpine salt deposit. Int $\mathrm{J}$ Syst Evol Microbiol 52:1807-1814

Sudesh K, Abe H, Doi Y (2000) Synthesis, structure and properties of polyhydroxyalkanoates: biological polyesters. Prog Polym Sci 25:1503-1555

Tomlinson GA, Hochstein LI (1976) Halobacterium saccharovorum sp. nov., a carbohydrate-metabolizing, extremely halophilic bacterium. Can J Microbiol 22:587-591

Ventosa A (2001) Genus II. Haloarcula Torreblanca, Rodriguez-Valera, Juez, Ventosa, Kamekura and Kates 1986b, 573 ${ }^{\text {VP }}$ (Effective publication: Torreblanca, Rodriguez-Valera, Juez, Ventosa, Kamekura and Kates 1986a, 98). In: Boone DR, Castenholz RW, Garrity GM (eds) Bergey's manual of systematic bacteriology, vol. I, 2nd edn. Springer Verlag, New York, pp 305-309

Witte A, Wanner G, Bläsi U, Halfmann G, Szostak M, Lubitz W (1990) Endogenous transmembrane tunnel formation mediated by phi X174 lysis protein E. J Bacteriol 172:4109-4114 